\title{
An analysis of competitive strategy for Taiwan's aerospace industry
}

\author{
Shu-Chen Chang', Guan-Yuan Lai ${ }^{2}$ \\ ${ }^{1}$ Department of Business Administration, National Formosa University \\ ${ }^{2}$ Graduate Institute of Business and Management, National Formosa University
}

\section{Email adress:}

shu-chen@.nfu.edu.tw (Shu-Chen Chang)

\section{To cite this article:}

Shu-Chen Chang, Guan-Yuan Lai. An Analysis of Competitive Strategy for Taiwan's Aerospace Industry. Social Sciences. Vol. 2, No. 2, 2013, pp. 48-52. doi: 10.11648/j.ss.20130202.14

\begin{abstract}
Previous studies related Taiwan's aerospace industry mainly focus on technical research and development, production and information management, and partnerships. However, these studies lack to investigate competitive strategy of Taiwan's aerospace industry using industrial organization theory. The main goal of this study is to investigate the current situation of the Taiwan's aerospace industry. This study uses the threestage least square method to estimate the relationship among the market structure, behavior and performance. The empirical results show that market share has significant and positive effect on businessperformance in the whole aerospace industry. R\&D investment ratio, the elasticity of capital use, the scale of domestic market, and the profit ratio have significant and positive impacts on the market share. In addition, the increases in profit ratio and human resources, as well as the electronic commerce could improve the capability of industrial R\&D.
\end{abstract}

Keywords: Competitive Strategy; Industrial Organization Approach; Three-Stage Least Squares

\section{Introduction}

Taiwan's economy has experienced the evolution from agriculture to industrialization and from commerce to the era of high-tech.The industry strategy has transformed from reward strategy to production strategy, and then finally to the research and development strategy. With the industry development, the electronics and information industries are fast-growing industries over the last decade. Because of the unique competitiveness in the domestic electronic and information technology, it leads to substantial growth in our national economy.

Furthermore, the traditional economies in domestic sectors have been declined due to the increase in labor wage, the emergence of environment protection consciousness, low wages and competitiveness in China, and low costs in other neighborhood countries.All those circumstances inevitably lead to an emerging situation of high-tech aerospace industry in Taiwan. The official promotion of Taiwan in the last decade has created substantial growth for the structural components, interior components, engine components and system components of aerospace industry.

Previous studies related Taiwan's aerospace industry focus on strategic development, logisticsmanagement, supply chain management and e-commerce, technological and human resources. However, these studies [1,2,3,4] lack to investigate competitive strategy of Taiwan's aerospace industry using industrial organization theory. The main goal of this study is to investigate the current situation of the Taiwan's aerospace industry. This study uses the three stages least square (3SLS) method to estimate the relationship among the market structure, behavior and performance.

\section{Empirical Model}

This study constructs three models including businessperformancemodel,market structure, and business strategy model.These three models are expressed as follows

Business performance model

$$
P C M_{i}=F\left(H H I_{i}^{d}, X D_{i}, H D_{i}, R D_{i}, P R_{i}, E B_{i}, K R_{i}\right)+\varepsilon_{1}(1)
$$

Market structure model

$$
H H I_{i}^{d}=F\left(P C M_{i}, H D_{i}, R D_{i}, E B_{i}, K R_{i}, E B C_{i}\right)+\varepsilon_{2}(2)
$$

Business strategy model 


$$
R D_{i}=F\left(P C M_{i}, H H I_{i}^{d}, L R_{i}, E B_{i}, D V_{i}, K R_{i}, E B C_{i}\right)+\varepsilon_{3}(3)
$$

where $P C M$ denotesbusinessperformancewhich is measured by profit rate. $R D$ denotes business strategy which is measured byR\&D ratio. $H H I^{d}$ denotesmarket structure which is measured by market share. $H D$ denotesdomestic sales, $X D$ denotesexport ratio, $P R$ denotesproduction equipment, $E B$ denotesaccess barrier, and KR denotescapitalmobility. $E B C$ denotese-business. $L R$ denotes labor intensity, and $D V$ denotes level of diversification.

We expected that market share has a positive influence on businessperformance. The R\&D ratio has an uncertain influence on businessperformance. The influence of export ratio on firm's profit depends on overseas and domestic profits. We expected that export ratio has an uncertain influence on businessperformance. Increases in domestic sales would increase the turnover and profit rate. Hence, domestic sales have a positive influence on businessperformance. The effect of entry barrier on businessperformance is expected a positive influence. With more production equipment, the manufacturer will have a greater economic scale and greater profits. Greater production scale has a positive influence on businessperformance. The effect of capital mobility on businessperformance is expected greater influence.

We expected that businessperformancea positive influence on the market structure. R\&D (i.e., to innovate products and to improve quality or process) will influence consumers' preferences and cause product diversity. Hence, $\mathrm{R} \& \mathrm{D}$ ratio has an uncertain influence on market structure. In addition, increases in domestic sales could improve the market share and industrial concentration. Therefore, we predict that the domestic manufacturer's ratio of domestic sales have a positive influence on the market share. We predict that access barrierhas a positive influence on market share. Capital mobility has a positive influence on market share. Moreover, if the manufacturer adopts more e-business systems to replace the manual systems, it will decrease the time cost in the supply chain and improve industrial competitiveness and market share. We predict that the adoption of an e-business system has a positive influence on market share.

Higher market share indicates a stronger monopoly of large manufacturers, who have strong professional teams as well as the capacity for technical development. We predict that the profit rate has a positive influence on $R \& D$ ratio. If a manufacturer chooses to distribute the operating risks by diversified operations, it will be actively involved in $R \& D$ to get more products and raw materials in its own market. The diversification has a positive influence on business strategy. With greater capital scale, a manufacturer can suppress its potential competitors more. We predict that the access barrierhas a positive influence on business strategy.

We predict that labor intensity has a positive influence on business strategy. With adequate capital supply, a manufacturer has greater R\&D capacity. Hence, we predict that capital mobility has a positive influence on business strat- egy. The influence of an e-business system on business strategy however is uncertain. The conjoint model with (1), (2), and (3) matrices is as follows,

$$
\begin{aligned}
& {\left[\begin{array}{ccc}
\beta_{11} & -\beta_{12} & -\beta_{13} \\
-\beta_{21} & \beta_{22} & -\beta_{23} \\
-\beta_{31} & -\beta_{32} & \beta_{33}
\end{array}\right]\left[\begin{array}{c}
P C M_{i} \\
H H I_{i}^{d} \\
R D_{i}
\end{array}\right]=\left[\begin{array}{c}
\alpha_{0} \\
\alpha_{1} \\
\alpha_{2}
\end{array}\right]} \\
& +\left[\begin{array}{cccccccc}
\alpha_{11} & \alpha_{12} & \alpha_{13} & 0 & 0 & 0 & \alpha_{17} & \alpha_{18} \\
0 & \alpha_{22} & \alpha_{23} & 0 & 0 & \alpha_{26} & 0 & \alpha_{28} \\
0 & 0 & \alpha_{33} & \alpha_{34} & \alpha_{35} & \alpha_{36} & 0 & \alpha_{38}
\end{array}\right]\left[\begin{array}{c}
X D_{i} \\
H D_{i} \\
E B_{i} \\
L R_{i} \\
D V_{i} \\
E B C_{i} \\
P R_{i} \\
K R_{i}
\end{array}\right]+\left[\begin{array}{c}
\varepsilon_{1} \\
\varepsilon_{2} \\
\varepsilon_{3}
\end{array}\right]
\end{aligned}
$$

where $\beta_{i j}$ is coefficients matrix of endogenous variables; $\alpha_{i j}$ is coefficients matrix of exogenous variables; $\alpha_{0}, \alpha_{1}, \alpha_{2}$ is intercept, $\varepsilon_{i}$ is matrix of error term which $E(\varepsilon)=0$, and $E\left(\varepsilon^{2}\right)=\sigma_{\varepsilon}^{2}$.

\section{Empirical Results}

To avoid inconsistent and biased of estimated results, this study used three-stage and least square method to simulate the interaction among market structure, businessperformance, and business strategy correctly. This paper adopted the 2001 survey statistics from the Industry, Commerce, and Service Census in Taiwan. The estimated results included upstream sector, midstream sector, downstream sector, and whole sector.These estimated results are expressed as follows.

\subsection{Upstream Sector}

In Table $1, R \& D$ ratio has a significant positive influence on profit rate (i.e., higher R\&D input will increase the profit). Access barrieralso showed a significant and positive influence (i.e., higher access barrierwill likewise increase the profit). Although domestic sales, market share, and capital mobility exhibited a positive influence on businessperformance, the effect was insignificant. The production scale, on the other hand, has a negative but insignificant influence onbusinessperformance. In the market structure model, the capital mobility significantly and positively influences the market share. This means that if the upstream manufacturer has adequate capital supply, then it will have a higher market share.

The domestic manufacturer's ratio of domestic sales has a significant and positive influence on market share (i.e., the domestic manufacturer will improve its market share when its ratio of domestic sales is improved), leading to a higher industrial concentration. Profit rate has a positive but insignificant relationship with e-business and market share. Moreover, $R \& D$ ratio and access barrierhave a nega- 
tive but insignificant influence on market share. In the business strategy model, labor intensity has a significant and positive influence on $\mathrm{R} \& \mathrm{D}$ ratio. This refers to the human resource adequacy of the manufacturer in relation to the $R \& D$ ratio. Likewise, the profit rate has a significant and positive influence on the $R \& D$ ratio which means that the manufacturer with a higher profit rate has a stronger capacity and adequate capital for R\&D. Moreover, e-business has a positive but insignificant influence on R\&D ratio. Capital mobility, market share, access barrier, and diversified operation showed a negative but insignificant influence on $R \& D$ ratio.

Table 1. The estimated results for upstream sector

\begin{tabular}{|c|c|c|c|}
\hline Variable & Profit rate & Market share & R\&D ratio \\
\hline Intercept & $\begin{array}{l}-22.55 \\
(-1.146)\end{array}$ & $\begin{array}{l}0.1981^{* *} \\
(2.588)\end{array}$ & $\begin{array}{l}54.378 \\
(-0.4523)\end{array}$ \\
\hline HHI & $\begin{array}{l}48.009 \\
(1.207)\end{array}$ & & $\begin{array}{l}-40.047 \\
(-0.0001)\end{array}$ \\
\hline $\mathrm{RD}$ & $\begin{array}{l}63.365^{*} \\
(1.813)\end{array}$ & $\begin{array}{l}-0.0028 \\
(-1.294)\end{array}$ & \\
\hline EB & $\begin{array}{l}5.3615 * * \\
(2.9663)\end{array}$ & $\begin{array}{l}-0.0071 \\
(-0.6223)\end{array}$ & $\begin{array}{l}-1.2022 \\
(-0.8627)\end{array}$ \\
\hline PR & $\begin{array}{l}-0.33454 \\
(-0.2127)\end{array}$ & & \\
\hline HD & $\begin{array}{l}1.1011 \\
(0.2916)\end{array}$ & $\begin{array}{l}0.0604^{* *} \\
(5.088)\end{array}$ & \\
\hline KR & $\begin{array}{l}31.954 \\
(1.583)\end{array}$ & $\begin{array}{l}0.0023^{*} \\
(1.878)\end{array}$ & $\begin{array}{l}-0.0695 \\
(-0.4523)\end{array}$ \\
\hline PCM & & $\begin{array}{l}0.0009 \\
(0.338)\end{array}$ & $\begin{array}{l}0.6039 * \\
(1.962)\end{array}$ \\
\hline EBC & & $\begin{array}{l}0.0503 \\
(0.9406)\end{array}$ & $\begin{array}{l}0.7993 \\
(0.1326)\end{array}$ \\
\hline LR & & & $\begin{array}{l}0.43023 * * \\
(3.064)\end{array}$ \\
\hline DV & & & $\begin{array}{l}-58.658 \\
(-0.0001)\end{array}$ \\
\hline Adj- $R^{2}$ & & 0.8956 & \\
\hline
\end{tabular}

Notes: The values in parentheses are $p$-values. ${ }^{* *}$ and ${ }^{*}$ indicate the variable is significant at the level of $10 \%$ and $5 \%$, respectively.

\subsection{Midstream Sector}

For business performance model in Table 2, the market share showed a significant and positive influence on profit rate (i.e., a manufacturer with a higher market share will increase its benefits). Moreover, access barrier, R\&D ratio, domestic manufacturer's ratio of domestic sales, and capital mobility have a positive but insignificant influence. The production scale has a negative and insignificant influence on profit rate. With regard to the market structure model, the profit rate has a positive and significant influence on market share (i.e., the manufacturer with a higher profit has a higher market share). R\&D ratio, access barrier, and e-business have positive but insignificant influences on market share. In the business strategy model, the profit rate exhibited a significant and positive influence on $R \& D$ ratio. This means that the manufacturer with a higher profit rate has a stronger capacity and more adequate capital for R\&D. Market share has a significant and positive influence on R\&D ratio (i.e., a larger manufacturer with a higher market share will have a high-degree monopoly, a stronger professional team, and a larger R\&D scale. In effect, the manufacturer will have more adequate capital for R\&D than the small competitors. Moreover, labor intensity, capital mobility, and diversified operation have a positive but insignificant influence on the $R \& D$ ratio, while e-business has a negative and insignificant influence.

Table 2. The estimated results for midstream sector

\begin{tabular}{|c|c|c|c|}
\hline Variable & Profit rate & Market share & R\&D ratio \\
\hline Intercept & $\begin{array}{l}14.041^{*} \\
(1.883)\end{array}$ & $\begin{array}{l}0.2278 * * \\
(1.991)\end{array}$ & $\begin{array}{l}679.64 \\
(0.0001)\end{array}$ \\
\hline HHI & $\begin{array}{l}56.308 * * \\
(3.528)\end{array}$ & & $\begin{array}{l}3.2368^{*} \\
(1.865)\end{array}$ \\
\hline $\mathrm{RD}$ & $\begin{array}{l}0.2945 \\
(1.012 .)\end{array}$ & $\begin{array}{l}0.0048 \\
(1.023)\end{array}$ & \\
\hline EB & $\begin{array}{l}0.0411 \\
(0.1321)\end{array}$ & $\begin{array}{l}0.0006 \\
(0.1237)\end{array}$ & $\begin{array}{l}-0.1894 \\
(-0.2869)\end{array}$ \\
\hline PR & $\begin{array}{l}-0.0943 \\
(-0.2831)\end{array}$ & & \\
\hline HD & $\begin{array}{l}0.0012 \\
(0.4155)\end{array}$ & & \\
\hline $\mathrm{KR}$ & $\begin{array}{l}0.0482 \\
(0.4140)\end{array}$ & $\begin{array}{l}0.0009 \\
(0.502)\end{array}$ & $\begin{array}{l}-0.1860 \\
(-0.6552)\end{array}$ \\
\hline PCM & & $\begin{array}{l}0.0177^{* *} \\
(3.716)\end{array}$ & $\begin{array}{l}3.2368^{*} \\
(1.865)\end{array}$ \\
\hline $\mathrm{EBC}$ & & $\begin{array}{l}0.0018 \\
(0.1380)\end{array}$ & $\begin{array}{l}-0.5868 \\
(-0.2394)\end{array}$ \\
\hline LR & & & $\begin{array}{l}0.1053 \\
(0.5176)\end{array}$ \\
\hline DV & & & $\begin{array}{l}-68.005 \\
(-0.0001)\end{array}$ \\
\hline Adj-R ${ }^{2}$ & & 0.4360 & \\
\hline
\end{tabular}

Notes: The values in parentheses are p-values. **and* indicate the varible is significant at the level of $10 \%$ and $5 \%$, respectively. 


\subsection{Downstream Sector}

In business performance model in Table 3, market share has a significant and positive influence on profit rate (i.e., a manufacturer with a higher market share will increase its profits). With regard to $R \& D$ ratio, it has a negative but significant influence on the market share. Although "access barrier" is formed when manufacturers engage in R\&D and create product diversity, the $R \& D$ result cannot be translated into profit rate within a short period. In fact, profit rate will even decline. With a higher $\mathrm{R} \& \mathrm{D}$ ratio, the manufacturer's current period of profit rate will be reduced. Furthermore, access barrierhas a significant and positive influence on profit rate. A manufacturer can improve its profit if it has capital mobility. In anycase, the production scale has a significant and positive influence on profit rate (i.e., a manufacturerwith a greater production scale will have higher profit). Likewise, the domestic manufacturer's ratio of domestic sales has a significant and positive influence on profit rate. With a higher ratio of domestic sales, the domestic manufacturer will increase its turnover. The capital mobility has a significant and positive influence on profit rate, thus a manufacturer with greater capital mobility will have greater profits. The domestic manufacturer's ratio of domestic sales has a significant and positive influence on market share. This means that the downstream manufacturer with a higher ratio of domestic sales has a higher market share and industrial concentration.

Table 3. The estimated results for downstream sector

\begin{tabular}{|c|c|c|c|}
\hline Variable & Profit rate & Market share & R\&D ratio \\
\hline Intercept & $\begin{array}{l}90.118 * * \\
(5.117)\end{array}$ & $\begin{array}{l}0.0094 * * \\
(5.863)\end{array}$ & $\begin{array}{l}-242.002 \\
(-0.0590)\end{array}$ \\
\hline HHI & $\begin{array}{l}57.749 * * \\
(19.58)\end{array}$ & & $\begin{array}{l}24.002 \\
(0.059)\end{array}$ \\
\hline $\mathrm{RD}$ & $\begin{array}{l}-16.247 * * \\
(-6.110)\end{array}$ & $\begin{array}{l}-0.0027 * * \\
(-6.782)\end{array}$ & \\
\hline EB & $\begin{array}{l}7.8847 * * \\
(4.207)\end{array}$ & $\begin{array}{l}0.0012 * * \\
(5.544)\end{array}$ & $\begin{array}{l}0.5477 * * \\
(2.968)\end{array}$ \\
\hline PR & $\begin{array}{l}3.0096 * \\
(1.739)\end{array}$ & & \\
\hline HD & $\begin{array}{l}15.875^{* *} \\
(12.67)\end{array}$ & $\begin{array}{l}0.0030 * * \\
(2.377)\end{array}$ & \\
\hline KR & $\begin{array}{c}0.3391 * * \\
(2.441)\end{array}$ & $\begin{array}{l}0.0005^{* * *} \\
(3.533)\end{array}$ & $\begin{array}{l}-0.0127 \\
(-0.8744)\end{array}$ \\
\hline PCM & & $\begin{array}{l}0.0001 * * \\
(8.284)\end{array}$ & $\begin{array}{l}0.0956 \\
(1.276)\end{array}$ \\
\hline EBC & & $\begin{array}{l}0.0001 \\
(0.3273)\end{array}$ & $\begin{array}{l}-0.3624 \\
(-0.9596)\end{array}$ \\
\hline LR & & & $\begin{array}{l}-0.0663 * * \\
(-2.313)\end{array}$ \\
\hline DV & & & $\begin{array}{l}24.000 \\
(0.0965)\end{array}$ \\
\hline $\operatorname{Adj}-R^{2}$ & & 0.8893 & \\
\hline
\end{tabular}

Notes: The values in parentheses are p-values. **and*indicate the variable is significant at the level of $10 \%$ and $5 \%$, respectively.
Based on the market structure model, R\&D ratio showed a positive influence on market share. As such, with a higher $\mathrm{R} \& \mathrm{D}$ ratio, the manufacturer will improve its market share. Additionally, access barrierhas a positive and significant influence (i.e., the manufacturer with capital mobility can improve the market share). The profit rate also shows a positive and significant influence. The manufacturer with a higher profit rate has a higher market share. As to the e-business system, it has a positive but insignificant influence. In the business strategy model, access barrierexhibits a positive influence on $\mathrm{R} \& \mathrm{D}$ ratio, thus a manufacturer with capital mobility can improve its $R \& D$ ratio. Labor intensity, for its part, has a significant and positive influence. In short, the manufacturer has adequate human resource for R\&D. Moreover, market share, profit rate, and extent of diversification have positive but insignificant influences on R\&D ratio. However, capital mobility and e-business have a negative but insignificant influence on $\mathrm{R} \& \mathrm{D}$ ratio.

In business performance model in Table4, the market share showed a significant and positive influence on profit rate (i.e., the entire aerospace market will enjoy extra profit if the market share is higher). In addition, $\mathrm{R} \& \mathrm{D}$ ratio, access barrier, and import/export ratio have a positive but insignificant influence on profit rate. However, production scale, capital mobility, and domestic sales showed negative but insignificant influences on profit rate. In market structure model, profit rate has a significant and positive influence on market share. The domestic manufacturer's ratio of domestic sales has a significant and positive influence on market share. In effect, the entire aerospace industry will improve its industrial concentration if the ratio of domestic sales is increased. With regard to capital mobility, which showed a significant and positive influence on market share, the entire aerospace industry will engage in R\&D by the flexible use of capital and thus expand the market share. However, the access barrierhas a positive but insignificant influence on market share. In the business strategy model, labor intensity has a significant and positive influence on the $R \& D$ ratio. This means that the industry has adequate human resources for R\&D. For its part, e-business has a significant and positive influence on $R \& D$ ratio (i.e., the entire aerospace industry can improve $R \& D$ greatly through the adoption of the e-business system. The profit rate has a significant and positive influence on the R\&D ratio, which means that the entire aerospace industry will enhance R\&D by increasing its profit rate since it has adequate capital for R\&D. However, market share, access barrier, capital mobility, and diversified operation have positive but insignificant influences on $\mathrm{R} \& \mathrm{D}$ ratio. 
Table 4. The estimated results of whole sector

\begin{tabular}{|c|c|c|c|}
\hline Variable & Profit rate & Market sh & R\&D ratio \\
\hline Intercept & $\begin{array}{l}42.526 \\
(1.021)\end{array}$ & $\begin{array}{l}-0.0280^{* *} \\
(-4.105)\end{array}$ & $\begin{array}{l}55.404 \\
(0.0010)\end{array}$ \\
\hline HHI & $\begin{array}{l}444.06 * * \\
(5.430)\end{array}$ & & $\begin{array}{l}553.73 \\
(0.0019)\end{array}$ \\
\hline $\mathrm{RD}$ & $\begin{array}{l}5.6602 \\
(0.9831)\end{array}$ & $\begin{array}{l}0.0059^{* *} \\
(7.258)\end{array}$ & \\
\hline EB & $\begin{array}{l}0.0955 \\
(0.0974)\end{array}$ & $\begin{array}{l}-0.0001 \\
(-0.4380)\end{array}$ & $\begin{array}{l}0.4715 \\
(0.9365)\end{array}$ \\
\hline PR & $\begin{array}{l}-0.0011 \\
(-0.0001)\end{array}$ & & \\
\hline KR & $\begin{array}{l}-0.1655 \\
(-0.9945)\end{array}$ & $\begin{array}{l}0.0001 * \\
(1.740)\end{array}$ & $\begin{array}{l}0.1132 \\
(1.548)\end{array}$ \\
\hline HD & $\begin{array}{l}-1.3733 \\
(-0.8154)\end{array}$ & $\begin{array}{l}0.0062 * * \\
(12.17)\end{array}$ & \\
\hline PCM & & $\begin{array}{l}0.0004 * * \\
(3.512)\end{array}$ & $\begin{array}{l}1.6225^{* *} \\
(2.041)\end{array}$ \\
\hline EBC & & $\begin{array}{l}-0.0028 \\
(-0.7432)\end{array}$ & $\begin{array}{l}7.494 * * \\
(1.899)\end{array}$ \\
\hline LR & & & $\begin{array}{l}0.8445^{* *} \\
(2.904)\end{array}$ \\
\hline DV & & & $\begin{array}{l}55.404 \\
(0.0010)\end{array}$ \\
\hline XD & $\begin{array}{l}430.53 \\
(0.6443)\end{array}$ & & \\
\hline Adj-R ${ }^{2}$ & & 0.688 & \\
\hline
\end{tabular}

Notes: The values in parentheses are p-values. ${ }^{* *}$ and ${ }^{*}$ indicate the variable is significant at the level of $10 \%$ and $5 \%$, respectively.

\section{Conclusion}

This study investigates influence the market structure, business performance, and strategy of the upstream, midstream, and downstream aerospace industry through three-stage least square method. Based on the empirical results, the upstream manufacturers can improve their performance by increasing the $\mathrm{R} \& \mathrm{D}$ ratio and lifting the access barrier. The flexible mobilization for capital and improving the ratio of domestic sales couldimprove market share.

By improving market share, midstream manufacturers would boost profit and performance. Performancecould improve market share. The higher profit rate and market share would boost R\&D capacity. The downstream manufacturers, on the other hand, would increase profit and improve businessperformance by expanding the market share, increasing the R\&D ratio, lifting the access barrier, improving the production scale, and boosting the capital mobility. The market share (i.e., the change in market structure) cane improved by expanding the $R \& D$ ratio, lifting the access barrier, improving the profit rate, increasing the scale of domestic sales, and boosting the capital mobility. The manufacturers' R\&D capacity will be increased by lifting the access barrierand increasing human resources.

The higher market share means higher profit rate. The expanding R\&D ratio, increasing capital mobility, and increasing the scale of domestic sales and profit rate could improve market share. The increasing the profit rate, and by the extensive and good use of e-business and human resources could increase R\&D capacity.

\section{References}

[1] Chang, Y.P. (2002), To Explore A Third-Party Logistics Business Model of Aerospace Industry in Taiwan, pp. $1-149$.

[2] Liaw, C.S. (1999), The Study for the Co-Existenance and Optimal Strategies Alliance between Each Aircraft Manufacturing Vendors in Taiwan, pp. 1-22.

[3] Weng, T.K. (2001), The Competitive Advantage Analysis of Aviation Industry in Taiwan, pp. 1-111.

[4] Wu, C.J. (2003), The Facilitating Factors of Adopting the Supply Chain Management Practices in Taiwanese Aviation Industry, pp.1-88. 